\title{
STUDY OF INTERMOLECULAR INTERACTIONS OF ANTIVIRAL AGENT TILORONE WITH RNA AND NUCLEOSIDES
} V.A. Pashynska ${ }^{1}$, N.M. Zholobak ${ }^{2}$, M.V. Kosevich ${ }^{1}$, A. Gomory ${ }^{3}$, P.K. Holubiev ${ }^{4}$, A.I. Marynin ${ }^{4}$

\author{
${ }^{I}$ B. Verkin Institute for Low Temperature Physics and Engineering of the National Academy of Sciences of \\ Ukraine, 47, Nauky Ave., Kharkov, 61103, Ukraine \\ e-mail:pashynska@ilt.kharkov.ua \\ ${ }^{2}$ D.K. Zabolotny Institute of Microbiology and Virology of the National Academy of Sciences of Ukraine, 154, \\ Acad. Zabolotnoho str., 03680, Kyiv, Ukraine \\ e-mail: n.zholobak@gmail.com \\ ${ }^{3}$ Institute of Organic Chemistry of Research Centre for Natural Sciences of the Hungarian Academy of Sciences, \\ Magyar tudosok korutja, 2, Budapest, H-1117, Hungary; \\ ${ }^{4}$ National University of Food Technologies, 68, Volodymyrska str., 01601, Kyiv, Ukraine
} Submitted January 29, 2017

Accepted February 23, 2018

\begin{abstract}
Background: While antiviral and interferon-inducing agent tilorone is used as a reactant of a number of popular pharmacological preparations, the molecular mechanisms of its biological antiviral activity are under discussions among the specialists. That is why the molecular level model studies of interactions of tilorone with targeting biomolecules and their components are considered to be urgent and useful for understanding the molecular mechanisms of the agent biological activity.

Objectives: The current model study is devoted to mechanistic examining of the intermolecular interactions of tilorone with its possible biomolecular targets which are believed to be nucleic acids and such their components as nucleosides containing purine or pyrimidine nitrogen bases.

Materials and methods: The objects of the study are model systems composed of tilorone dihydrochloride (Til $2 \mathrm{HCl})$ and its potential targeting biomolecules: single-stranded RNA (ssRNA) obtained from Saccharomyces cerevisiae yeast or nucleosides - adenosine (Ado), thymidine (Thd), or uridine (Urd). Dynamic light scattering (DLS) measurements aimed at observation of drug-biomolecules aggregation is applied to the system (tilorone+ssRNA) (1:10 molar ratio) in RNA-free phosphate buffered saline solution (with $10 \%$ fetal bovine serum). Electrospray ionization (ESI) mass spectrometry is used to examine the intermolecular interactions in the binary (tilorone + nucleoside) (Ado, or Thd, or Urd in 1:10 molar ratio) and triple (tilorone + Ado + Urd) (1:10:10 molar ratio) systems dissolved in polar solvent methanol.
\end{abstract}

Results: The obtained DSL data demonstrate that under conditions similar to the physiological ones, introduction of tilorone into the ssRNA solution results in formation of tilorone+ssRNA aggregates which more than 10 times exceed in size the particles observed in the ssRNA solution itself. The ESI mass spectrometry experiments reveal that while the mass spectra of all studied (tilorone + nucleoside) model systems contain ions characteristic of the individual components of the mixtures, in the spectra of (tilorone + Urd) system the ions of stable ion-molecular clusters of uridine with tilorone dication $\mathrm{Urd} \cdot \mathrm{Til} \bullet 2 \mathrm{H}^{2+}$ are recorded. The examining of the three-component model system (tilorone + Ado $+\mathrm{Urd}$ ) testifies to the selectivity of tilorone binding: while the peak of noncovalent complex of Urd $\bullet \mathrm{Til}^{\circ} \cdot 2 \mathrm{H}^{2+}$ is detected, any peaks of the complexes of Ado with tilorone are not found in the mass spectrum.

Conclusions: Formation of large-scale molecular aggregates of tilorone with ssRNA in the solutions which are similar to the physiological solution in physical and chemical characteristics is revealed in the performed DLS investigation. Creation of stable Urd $\bullet$ Til $\cdot 2 \mathrm{H}^{2+}$ noncovalent complexes in (tilorone + nucleoside) model systems was demonstrated by ESI mass spectrometry, while the complexes of tilorone with Ado and Thd are not detected in the experiments. It testifies to the possibility of formation of stable noncovalent complexes of tilorone with ssRNA and their components in biological systems, and pointed at Urd as one of the potential centers of specific binding of RNA molecules with tilorone.

KEY WORDS: tilorone; RNA; nucleosides; intermolecular interactions; dynamic light scattering; mass spectrometry.

(C) Pashynska V.A., Zholobak N.M., Kosevich M.V., Gomory A., Holubiev P.K., Marynin A.I., 2018 


\author{
ВИВЧЕННЯ МІЖМОЛЕКУЛЯРНОЇ ВЗАЕМОДІЇ АНТИВІРУСНОГО АГЕНТУ \\ ТИЛОРОНУ 3 РНК ТА НУКЛЕОЗИДАМИ \\ Пашинська В.А. ${ }^{1}$, Жолобак Н.М. ${ }^{2}$, Косевич М.В. ${ }^{1}$, Гоморі А. ${ }^{3}$, \\ Голубєв П.К. ${ }^{4}$, Маринін А. I. $^{4}$ \\ ${ }^{I}$ Фізико-технічний інститут низьких температур ім. Б.І. Вєркіна Національної академії наук України, \\ 47, пр. Науки, Харків, 61103, Украӥна \\ e-mail: pashynska@ilt.kharkov.ua \\ ${ }^{2}$ Інститут мікробіології і вірусології ім. Д.К. Заболотного Національної академії наук України, \\ 154, вул. Академіка Заболотного, Київ, 03680, Україна \\ e-mail:n.zholobak@gmail.com \\ ${ }^{3}$ Інститут органічної хімії Наукового иентру природничих наук Угорської академії наук, \\ Magyar tudosok korutja, 2, Budapest, H-1117, Hungary; \\ ${ }^{4}$ Національний університет харчових технологій, 68, вул. Володимирська, Київ, 0160, Україна
}

Актуальність. Незважаючи на застосування антивірусного та інтерферон-індукуючого агенту тилорону в якості діючої речовини ряду сучасних фармакологічних препаратів, молекулярні механізми його антивірусної дії залишаються предметом наукової дискусії. Тому дослідження на молекулярному рівні взаємодії тилорону з біомолекулами-мішенями та їх компонентами $€$ актуальними та важливими з точки зору встановлення молекулярних механізмів його біологічної активності.

Мета роботи. Метою роботи стало вивчення міжмолекулярних взаємодій тилорону 3 потенційними біомолекулами-мішенями: нуклеїновими кислотами та їх компонентами нуклеозидами, що можуть містити, як пуринові, так і піримідинові азотисті основи.

Матеріали і методи. Об'єктами дослідження було обрано модельні системи, що містили тилорону дигідрохлорид та потенційні молекули-мішені одноланцюгові PHК (ssRNA), які було отримано 3 дріжджів Saccharomyces cerevisiae, або нуклеозиди: аденозин (Ado), тимідин (Thd), чи уридин (Urd). Маючи за мету вивчення можливої агрегації тилорону з біомолекулами, методом динамічного розсіювання світла було досліджено систему (тилорон+РНК) (молярне співвідношення компонентів 1:10) у розчині, в складі якого - натрій-фосфатний буфер 3 додаванням $10 \%$ сироватки крові теляти. Метод мас-спектрометрії 3 іонізацією електророзпиленням було застосовано для дослідження міжмолекулярних взаємодій в модельних бінарних системах (тилорон+нуклеозид) (Ado або Thd, або Urd, молярне співвідношення 1:10) та трьохкомпонентній системі (тилорон + Ado + Urd) (молярне співвідношення 1:10:10), які було розчинено в полярному розчиннику - метанолі.

Результати. Дані, отримані методом динамічного розсіювання світла, свідчать, що в умовах, наближених до фізіологічних, введення тилорону у розчин РНК призводить до формування в системі молекулярних агрегатів тилорон+ssRNA, які у 10 разів перевищують за розміром частинки, присутні у вихідному розчині РНК. Результати мас-спектрометричного експерименту показують, що мас-спектри усіх досліджених бінарних систем (тилорон+нуклеозид) містять піки іонів, які характерні для індивідуальних компонентів сумішей, а в спектрі системи (тилорон + Urd) поряд $з$ вищезазначеним реєструється досить інтенсивний сигнал стабільного іон-молекулярного кластеру Urd•Til• $2 \mathrm{H}^{2+}$. Мас-спектрометричне дослідження трьохкомпонентної модельної системи (тилорон + Ado + Urd) підтвердило дані щодо можливої вибірковості зв'язування тилорону 3 нуклеозидами, оскільки при наявності у спектрі сигналу нековалентного комплексу Urd•Til• $2 \mathrm{H}^{2+}$ піки кластерів Ado з тилороном в спектрі не виявлено.

Висновки. Методом динамічного розсіювання світла показано формування великорозмірних молекулярних агрегатів тилорону з РНК у розчині, який за фізико-хімічними параметрами наближений до фізіологічного. В дослідженнях методом мас-спектрометрії 3 іонізацією електророзпиленням виявлено утворення стабільних нековалентних комплексів Urd•Til• $2 \mathrm{H}^{2+}$ в модельних системах (тилорон + нуклеозид), утворення комплексів тилорону 3 Ado чи Thd не зареєстровано. Отримані дані свідчать про можливість формування стабільних нековалентних комплексів тилорону з одноланцюговими РНК та ї компонентами в біологічних системах та вказують на Urd як на один 3 потенційних центрів специфічного зв'язування молекул РНК 3 тилороном.

КЛЮЧОВІ СЛОВА: тилорон; РНК; нуклеозиди; міжмолекулярна взаємодія; динамічне розсіювання світла; мас-спектрометрія. 
Study of intermolecular interactions of antiviral agent tilorone with RNA and nucleosides.

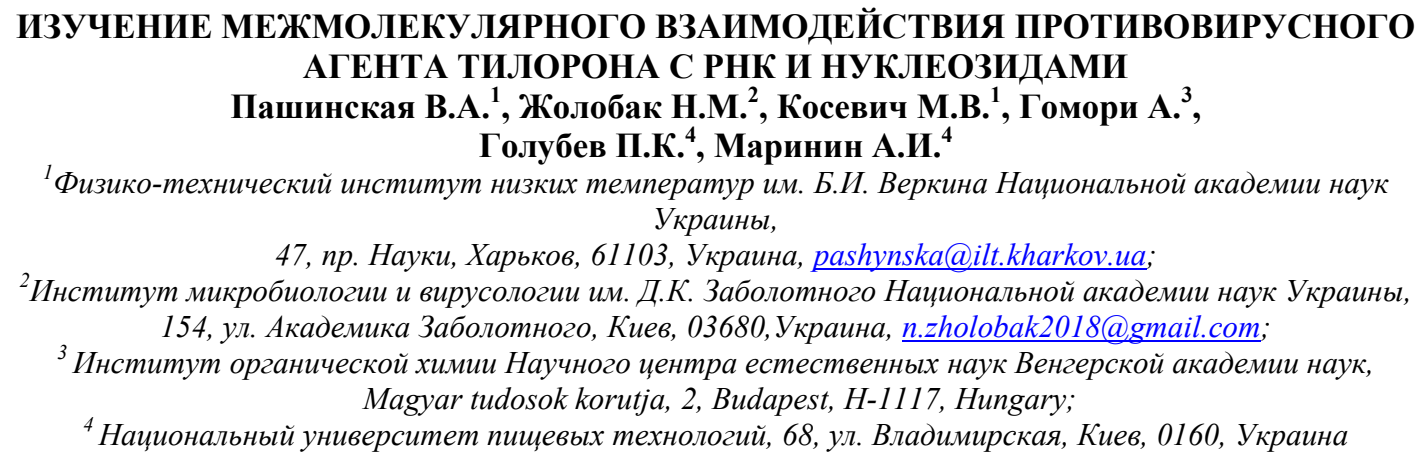

Актуальность. Несмотря на использование противовирусного и интерферон-индуцирующего агента тилорона в качестве действующего вещества ряда современных фармакологических препаратов, молекулярные механизмы его антивирусного действия остаются предметом научной дискуссии. Поэтому исследования на молекулярном уровне взаимодействий тилорона с потенциальными биомолекулами-мишенями и их компонентами являются актуальными и важными для определения молекулярных механизмов его биологической активности.

Цель работы. Целью настоящей работы стало изучение межмолекулярного взаимодействия тилорона с потенциальными биомолекулами-мишенями: нуклеиновыми кислотами и их компонентами нуклеозидами, содержащими как пуриновые, так и пиримидиновые азотистые основания.

Материалы и методы. Объектами исследования были выбраны модельные системы, состоявшие из дигидрохлорида тилорона и его потенциальных молекул-мишеней одноцепочечных РНК (ssRNA), полученных из дрожжей Saccharomyces cerevisiae, или нуклеозидов: аденозина (Ado), тимидина (Thd), или уридина (Urd). C целью изучения возможной агрегации тилорона с биомолекулами методом динамического светорассеяния была исследована система (тилорон + РНК) (молярное соотношение компонентов 1:10) в растворе натрий-фосфатного буфера с добавлением $10 \%$ сыворотки крови телят. Метод масс-спектрометрии с ионизацией электрораспылением был использован для исследования межмолекулярных взаимодействий в модельных бинарных системах (тилорон+нуклеозид) (Ado или Thd, или Urd, молярное соотношение $1: 10$ ) и трехкомпонентной системе (тилорон + Ado + Urd) (молярное соотношение 1:10:10), растворенных в полярном растворителе метаноле.

Результаты. Данные, полученные методом динамического светорассеяния, свидетельствуют, что в условиях, приближенных к физиологическим, введение тилорона в раствор РНК вызывало формирование в модельной системе агрегатов тилорон+ssRNA, которые более чем в 10 раз превышали по размеру частицы, присутствовавшие в исходном растворе РНК. Экспериментальные результаты, полученные методом масс-спектрометрии, демонстрируют, что масс-спектры всех исследованных бинарных систем (тилорон+нуклеозид) содержат пики ионов, характерных для индивидуальных компонентов смеси, а в спектре системы (тилорон + Urd), наряду с этим, обнаружен достаточно интенсивный сигнал стабильного ион-молекулярного кластера Urd•Til• $2 \mathrm{H}^{2+}$. Мacc-спектрометрическое исследование трехкомпонентной модельной системы (тилорон + Ado + Urd) подтвердило данные о возможной селективности связывания тилорона с нуклеозидами, поскольку при наличии в спектре системы пика нековалентного комплекса Urd•Til•2 $\mathrm{H}^{2+}$ пики кластеров Ado с тилороном в спектре не обнаружены.

Выводы. Методом динамического светорассеяния показано формирование крупных молекулярных агрегатов тилорона с РНК в растворе, близком по физико-химическим параметрам к физиологическому. В исследованиях методом масс-спектрометрии с ионизацией электрораспылением продемонстрировано образование стабильных нековалентных комплексов $\mathrm{Urd} \cdot \mathrm{Til} \cdot 2 \mathrm{H}^{2+}$ в модельных системах (тилорон + нуклеозид). Комплексы тилорона с Ado и Thd в спектрах не зарегистрированы. Полученные данные свидетельствуют о возможности формирования стабильных нековалентных комплексов тилорона с одноцепочечными РНК и их компонентами в биологических системах и указывают на Urd как на один из потенциальных центров специфического связывания молекул РНК с тилороном.

КЛЮЧЕВЫЕ СЛОВА: тилорон; РНК; нуклеозиды; межмолекулярные взаимодействия; динамическое светорассеяние; масс-спектрометрия.

Tilorone is known as an effective antiviral and interferon-inducing agent from the seventies of the last century [1-3]. Tilorone is a reactant of the national pharmaceutical preparation Amixin IC (InterChem SLC, Odessa, Ukraine) and some other preparations which 
are widely used in the treatment of a number of viral infections and some other diseases [4-8]. The interferon-inducing action of tilorone and, in particular, stimulation of synthesis of all three types of interferon in a human body is considered as the basic mechanism of the preparation activity [9].

However, in spite of active usage of tilorone in medical practice in Ukraine and some others FSU countries, the discussions about its efficiency and investigations of its pharmacological activity as well as toxicity are currently continued [10-12]. For example, there is investigation testified to miscoordination of interferon-inducing and antiviral effects of tilorone [13]. The problem of molecular mechanisms of antiviral tilorone activity is remaining open since it is still not clear whether this activity is related just to interferoninducing activity or it is also connected with other intracellular cascade reactions and intermolecular interactions. That is why the molecular level model studies of interactions of tilorone with potential targeting biomolecules and their components are considered to be helpful in understanding the molecular mechanisms of the agent biological activity, which is necessary for development of more efficient and less toxic medicines. In particular, one of the existing hypotheses about nucleic acids and their constituents as potential molecular targets for tilorone binding requires experimental confirmation.

The current study is devoted to examining the mechanistic intermolecular interactions of tilorone with its possible molecular targets in the viral and host cells, which are believed to be RNA and nucleosides. An experimental investigation of biologically significant intermolecular interactions of tilorone with ssRNA and a number of nucleosides (adenosine (Ado), thymidine (Thd), and uridine (Urd)) has been performed by dynamic light scattering (DLS) and electrospray (ESI) ionization mass spectrometry methods.

\section{MATERIALS AND METHODS}

\section{Materials}

Tilorone-2,7-bis[2-(diethylamino)ethoxy]-9-fluorenone dihydrochloride from the Sigma-Aldrich company (Germany) was used in all experimental investigations. The chemical structure of tilorone dihydrochloride $(\mathrm{Til} \cdot 2 \mathrm{HCl})$ is presented in Scheme 1.

Single-stranded RNA (ssRNA) for DLS experiments was obtained from Saccharomyces cerevisiae yeast as described in [14]. The following dilution buffer composition was used as a solvent: RNA-free phosphate buffered saline solution (PBS, Sigma, USA) and 10\% (volume to volume) of fetal bovine serum (FBS, Sigma, USA), $\mathrm{pH}=7.4$. After preparation of solutions of tilorone $\left(10 \mathrm{~g} \cdot \mathrm{L}^{-1}\right.$ or $\left.2.07 \cdot 10^{-2} \mathrm{~mol} \cdot \mathrm{L}^{-1}\right)$ and ssRNA $\left(8 \mathrm{~g} \cdot \mathrm{L}^{-1}\right)$ in the above mentioned solvent, they were ex tempore filtered through $0.2 \mu \mathrm{m}$ syringe filter Minisart ${ }^{\circledR}$ NML with surfactant-free cellulose acetate (SFCA) (Sartorius AG, Germany). The samples of the model system (tilorone + ssRNA) were prepared just before DLS measurements by mixing of the two solutions to obtain the final molar ratio of tilorone to ssRNA as 1:10.

Adenosine (Ado), thymidine (Thd), and uridine (Urd) nucleosides and methanol $(\mathrm{MeOH})$ for mass spectrometric experiments were purchased from the Sigma-Aldrich company (Germany). Initial solutions of tilorone and nucleosides $(5 \mathrm{mM})$ were prepared in methanol (polar solvent which is commonly used in ESI mass spectrometry) and used for preparation of binary (tilorone + nucleoside) $(1: 10$ molar ratio) and triple (tilorone + Ado + Urd) $(1: 10: 10$ molar ratio) model systems. In our study we did not investigate the model systems including guanosine, since from our previous experimental experience we know that guanine derivatives have less solubility in polar solvents in comparison with other nucleosides. It could result in distortion of mass spectrometric information about intermolecular interactions in the multicomponent model systems containing guanosine. 
Study of intermolecular interactions of antiviral agent tilorone with RNA and nucleosides.

The mixtures were kept at the room temperature for at least 10 minutes before the ESI mass spectrometric analysis. The spraying procedure required dilution of the solutions to be studied to the final $250 \mu \mathrm{M}$ concentration of the diluted components of the model systems in each solution.<smiles>CCN(CC)CCOc1ccc2c(c1)C(=O)c1cc(OCCN(CC)CC)ccc1-2</smiles>

Scheme 1. Tilorone dihydrochloride (Til $2 \mathrm{HCl}$ ) chemical structure (adapted from the web site of the SigmaAldrich supplier https:/www.sigmaaldrich.com/catalog/product/aldrich/220957?lang=en\&region=UA).

\section{Dynamic light scattering}

Dynamic light scattering (DLS) method, which is also known as photon correlation spectroscopy, is a powerful tool for studying the size distribution of molecular particles, and in particular their aggregates, basing on their diffusion behavior in solution. The diffusion coefficient, and hence the hydrodynamic radii calculated from it, depends on the size and shape of the particles present in solutions.

The particles sizes and distribution as well as polydispersity indexes (PdI) of solutions of ssRNA and (tilorone + ssRNA) mixture in the dilution buffer are measured using Malvern Zetasizer Nano-ZS instrument (Malvern Instruments Ltd., Malvern, UK) and analyzed by Zetasizer software (Malvern Instruments). For each sample a separate disposable polystyrene cuvette (Sarstedt AG \& Co., Germany) is used. Water is used as a dispersant. All DSL measurements are carried out at a standard temperature of $+25^{\circ} \mathrm{C}$, and three measurements with at least 10 sub-runs are performed for each sample.

The Zetasizer software supplied with the instrument provides a number of analysis tools to study aggregation by the DLS. "Size Distribution by Intensity" and "Size Distribution by Volume" are the most widely used tools. The Size Distribution by Intensity method is suitable for detection of high molecular weight particles including aggregates, which scatter light disproportionately relative to smaller particles, enabling detection despite their relatively low concentration in a sample [15]. The Size Distribution by Volume method is used in our study with the aim to investigate of characteristics of the particles of ssRNA and aggregates in (tilorone + ssRNA) system in the dilution buffer.

\section{ESI mass spectrometry}

Electrospray ionization (ESI) mass spectra of the systems studied are obtained in the positive ion mode using triple quadrupole (QqQ) Micromass Quattro Micro mass spectrometer (Waters, Manchester, UK) equipped with the electrospray ion source. This source is operated in the standard ESI mode. The ESI source temperature is set to $120^{\circ} \mathrm{C}$ and the desolvation temperature is $200^{\circ} \mathrm{C}$. The spraying capillary is operated at $3.5 \mathrm{kV}$. The cone voltage $(\mathrm{CV})$ value of $10 \mathrm{~V}$ is used. The analyzed solutions $(20 \mu \mathrm{L})$ are injected into the mass spectrometer at a constant flow rate of $0.2 \mathrm{~mL} \cdot \mathrm{min}^{-1}$ of methanol solvent. The ESI spectra are recorded in the mass range of $m / z$ 100-2000. Data acquisition and processing are performed using MassLynx 4.1 software (Waters, Manchester, UK).

\section{RESULTS AND DISCUSSION}

\section{DSL experimental study}

DLS method was applied to examine the size characteristics of the particles present in solutions of ssRNA and (tilorone + ssRNA) system (1:10 molar ratio) in the dilution 
buffer. The obtained (PdI) and Size Distribution by Intensity values are summarized in Table 1.

Table 1. Polydispersity Index (PdI), Size Distribution by Intensity and Z-Average data for solutions of ssRNA and (tilorone + ssRNA) in dilution buffer *

\begin{tabular}{cccc}
\hline & Parameter & ssRNA solution & $\begin{array}{c}\text { (tilorone }+ \text { ssRNA) system } \\
(1: 10 \text { molar ratio })\end{array}$ \\
\hline \multicolumn{2}{c}{ Size Distribution by Intensity } & $0.192 \pm 0.009$ & $0.330 \pm 0.062$ \\
\hline \multirow{2}{*}{ Pk 1} & Mean Int $(\mathrm{d}, \mathrm{nm})$ & $152.6 \pm 1.99$ & $1882 \pm 139.5$ \\
\cline { 2 - 4 } & Area Int $(\%)$ & 100 & $75 \pm 18$ \\
\hline \multirow{2}{*}{ Pk 2} & Mean Int $(\mathrm{d}, \mathrm{nm})$ & - & $5096 \pm 474.4$ \\
\cline { 2 - 4 } & Area Int $(\%)$ & - & $25 \pm 18$ \\
\hline Z-Ave & $\mathrm{nm}$ & $126.43 \pm 1.63$ & not applicable \\
\hline
\end{tabular}

*Notes: the results are presented as Mean and St Deviation; the Size Distribution by Intensity data are represented as a certain number of peaks ( $\mathrm{Pk} 1-2)$ corresponding to the populations of particles of certain size (Mean Int $-\mathrm{d}, \mathrm{nm}$ ) and their input into the total scattering intensity (Area Int - \%). Z-Average size (Z-Ave) is harmonic intensity averaged particle diameter.

The summarized data on the particles Size Distribution by Volume are presented in Table 2.

Table 2. Particles Size Distribution by Volume in solutions of ssRNA and (tilorone + ssRNA)

\begin{tabular}{cc}
\hline Solutions & Particles Size Distribution $(\mathrm{d}, \mathrm{nm} \pm$ St Dev) by Volume \\
\hline ssRNA & $132.1 \pm 67.1$ \\
\hline (tilorone + ssRNA) & $1711.0 \pm 351.0$ \\
\hline
\end{tabular}

Statistic graphs of the particles size distributions in solutions of ssRNA and (tilorone + ssRNA) system by volume are presented in Fig. 1.

The experimental results demonstrate that ssRNA solution in the dilution buffer is quite monodisperse system, since it contains particles of similar sizes. Indeed, the mean diameter of these particles is between 150 and $154 \mathrm{~nm}$ and the size distribution is narrow, as is evidenced by the polydispersity index values (ranging from 0.18 to 0.20 ) (Table 1 ). The data obtained for PdI and Size Distribution by Intensity for the ssRNA solution most probably point to creation of similar sizes molecules aggregates of ssRNA with Bovine Serum Albumin (BSA) and/or other molecules existing in the used buffer solution ( $\mathrm{Pk} 1$ in Table 1, peak in the statistic graph, Fig. 1). Value of Z-average (also known as the "cumulants mean") testifies to the monodispersity of the ssRNA solution sample too.

Introduction of tilorone solution into the solution of ssRNA in the buffer resulted in almost twice reliable increase of PdI values (range of PdI value is $0.27-0.39$ ) comparing with the values for the ssRNA solution itself. In the statistic graph of (tilorone + ssRNA) system (Fig. 1) there are two peaks showing the presence of two different size particles populations in the system. The first peak (which input into the total scattering intensity is $75 \%$ ) is most probably related to aggregates of tilorone with the initial particles of ssRNA, and mean diameter of the aggregates is more than 10 times exceeds the mean diameter of the particles in the ssRNA solution itself. The second peak (with input into the total scattering intensity of $25 \%$ ) is related to bigger aggregates of the system components (obviously, including BSA and other serum components) with the mean diameter ranging between 4.62 and $5.57 \mu \mathrm{m}$. 
Study of intermolecular interactions of antiviral agent tilorone with RNA and nucleosides.

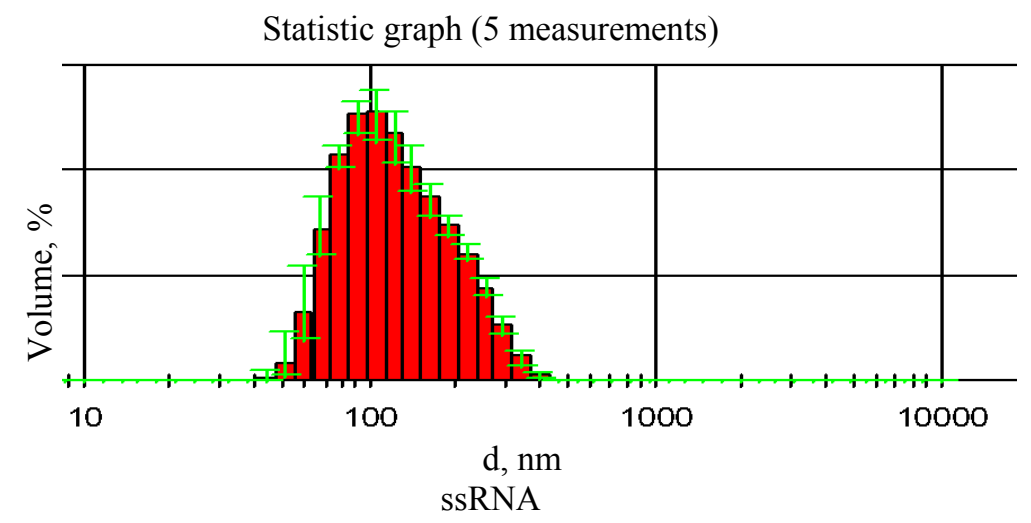

Statistic graph (2 measurements)

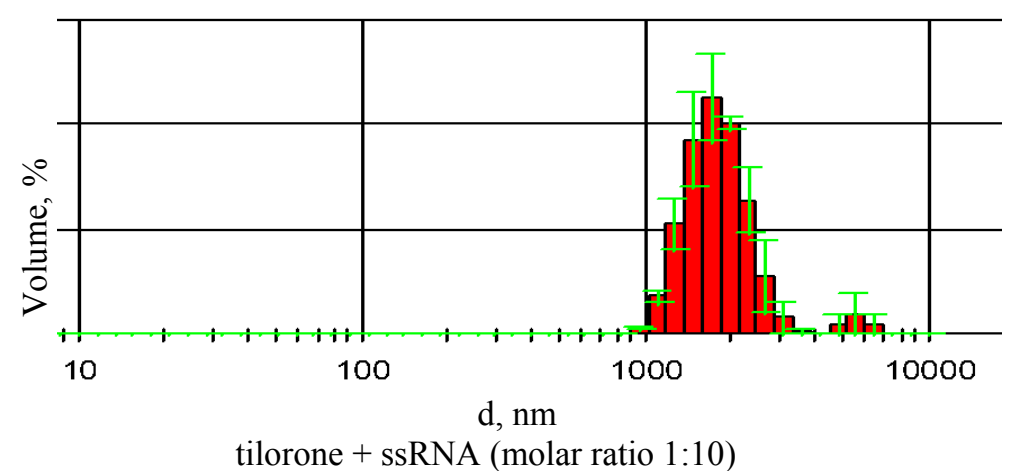

Fig. 1. Particles size distribution in solutions of ssRNA and (tilorone+ssRNA) system by volume. The results are presented as Mean with Max-Min error bar.

It should be noted that in our investigation, with the purpose of obtaining reliable results for sizes distribution and taking into account the ranges of the equipment sensitivity, we take solutions which contained more high concentrations of tilorone and ssRNA than usually are used for biological objects in vitro [16, 17].

Thus, the obtained DSL data demonstrate that under conditions similar to the physiological ones, the introduction of tilorone into the system of ssRNA solution in the buffer results in active aggregation of tilorone with the ssRNA particles and in enlargement of the aggregates likely contained tilorone, ssRNA and other components of the used dilution buffer. Earlier it was showed that (tilorone + ssRNA) complex with 1:10 components ratio demonstrated significant antiviral activity [16], and also induced interferon formation in vitro [17] as well as in vivo [18]. The data obtained in the current and earlier investigations are in a good agreement with the modern ideas about the effect of double-stranded allogenic RNA of different length on the formation of interferon-mediated or interferon independent antiviral resistance of the cells $[19,20]$.

To confirm the (tilorone + ssRNA) noncovalent complexation at the monomer level and with the purpose to find the possible RNA components which can be considered as centers of tilorone binding to the nucleic acid molecules, the following ESI mass spectrometry study of interactions of tilorone with nucleosides was performed.

\section{ESI mass spectrometry investigations}

At the first stage of the ESI mass spectrometric experimental study solution of tilorone in methanol was investigated. The characteristic mass spectrum of tilorone is presented in Fig. 2. It contains the abundant peak of the tilorone dication Til• $2 \mathrm{H}^{2+}(\mathrm{m} / \mathrm{z} 206.3)$ and set of clusters of tilorone with various number of protons and chlorine anions. 


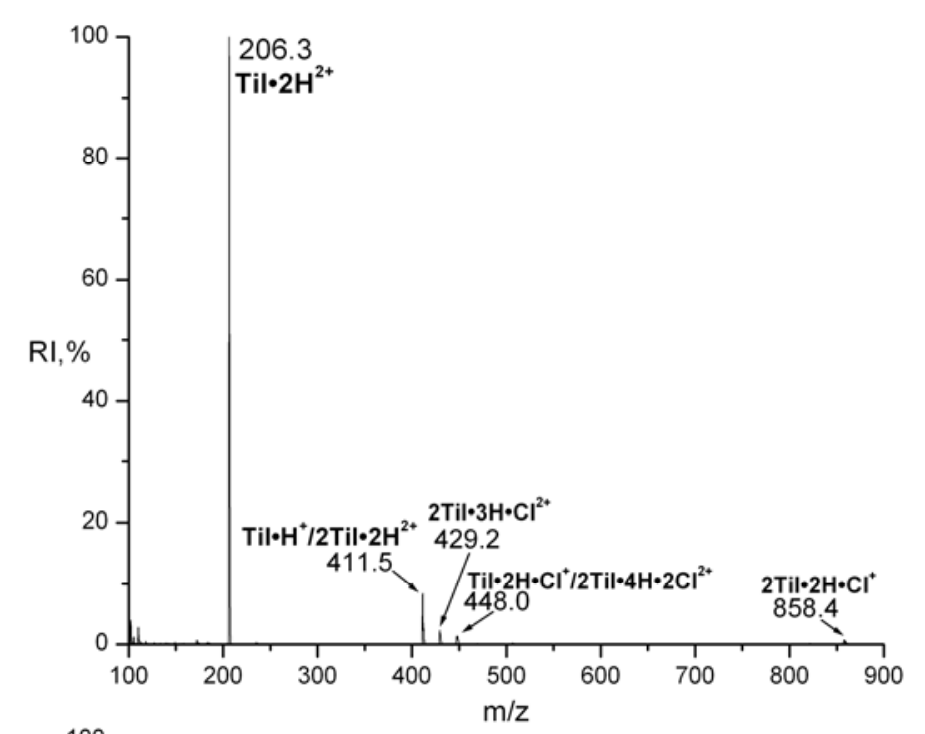

Fig. 2. Positive ion ESI mass spectrum of tilorone solution in methanol.

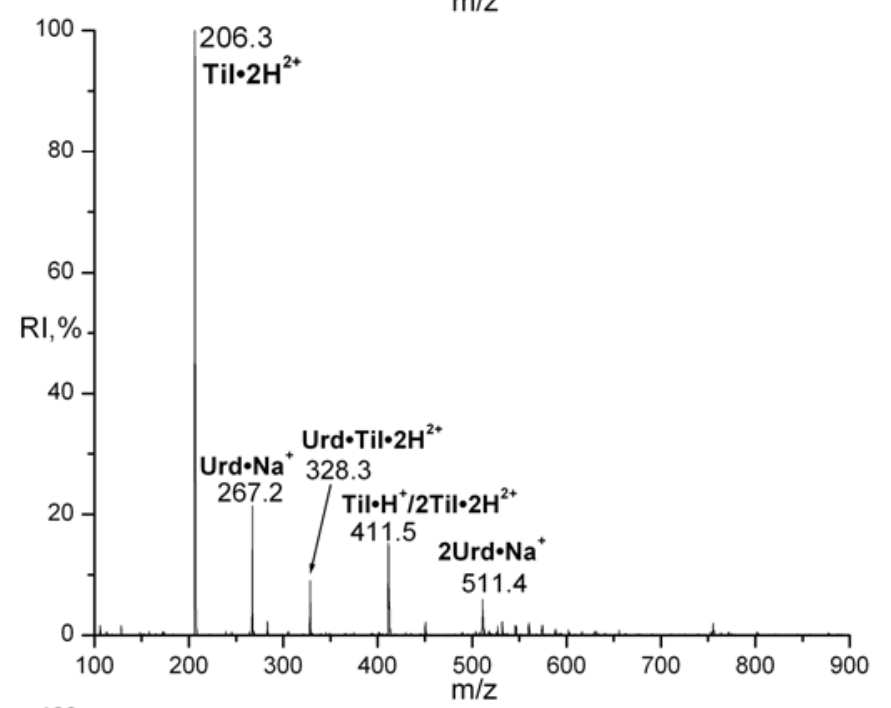

Fig. 3. ESI mass spectrum of (tilorone + Uridine) (1:10 molar ratio) model system in methanol solvent.

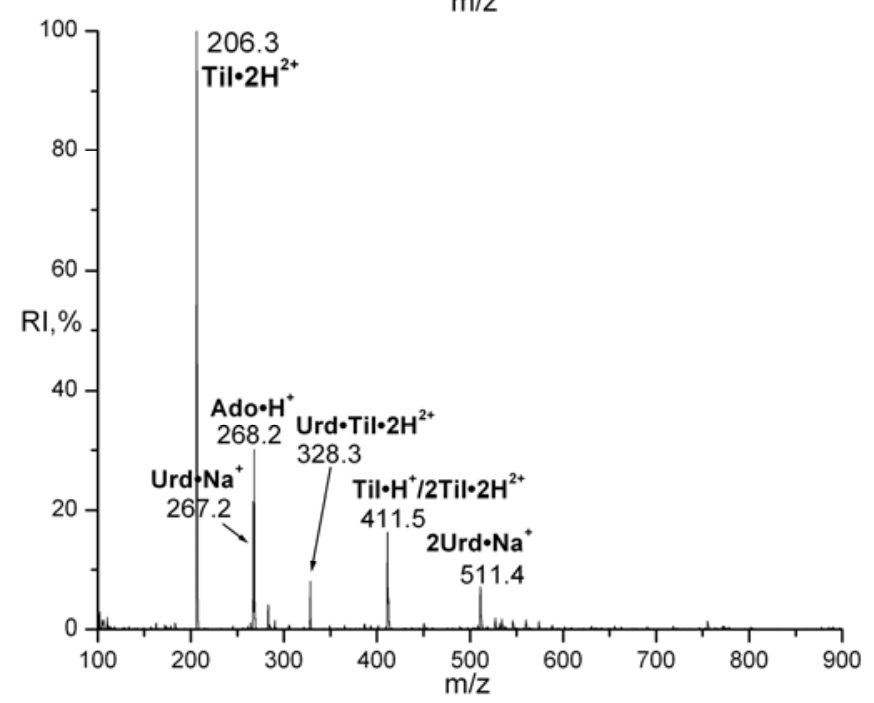

Fig. 4. ESI mass spectrum of (tilorone + Adenine + Uridine) $(1: 10: 10)$ model system in methanol solvent.

At the next stage the intermolecular interactions of tilorone with selected nucleosides Ado, Thd, and Urd were examined by the ESI mass spectrometry probing of methanol solutions of (tilorone + nucleoside) mixtures in 1:10 molar ratio. In the current measurements, we applied the ESI approach, which we developed and effectively harnessed in our previous investigations [21-25] for the study of intermolecular interactions of biologically active compounds, including drugs, with the targeting biological molecules. 
Study of intermolecular interactions of antiviral agent tilorone with RNA and nucleosides.

The mass spectra of all studied model systems (tilorone + nucleoside) contain ions characteristic of the individual components of the mixtures. At the same time, the most interesting result from the biophysical point of view relates to observation in the spectra of (tilorone + Urd) system (Fig. 3) the ions of stable ion-molecular clusters of uridine with tilorone dication. The presence of the peak of doubly charged ion Urd $\bullet$ Til $2 \mathrm{H}^{2+}(\mathrm{m} / z$ 328.3) with relative intensity about $10 \%$ in the ESI mass spectrum testifies to the formation of stable noncovalent complexes of uridine with tilorone in solution. It is notable that in the other model systems examined the formation of such complexes of tilorone with adenosine or thymidine is not detected by the ESI method.

To check the idea about selectivity of tilorone interaction with uridine we examined a three-component model system of (tilorone+Ado+Urd) (1:10:10 molar ration). The ESI mass spectrum of the triple system (Fig. 4) contains characteristic peaks of tilorone, adenosine, and uridine. The signal of the cluster of tilorone with uridine the peak of Urd $\bullet T$ Til $\bullet 2 \mathrm{H}^{2+}$ at $m / z 328.3$ has been detected too, while the peak of the complex Ado $\bullet$ Til $\bullet 2 \mathrm{H}^{2+}$ with expected $\mathrm{m} / \mathrm{z} 339.4$ or other peaks of any noncovalent complexes of adenosine with tilorone have not been found in the spectrum.

To determine the structural and energetic parameters of the registered in the mass spectrometry experiments noncovalent complexes of tilorone with uridine we are planning to perform quantum-mechanical calculations in our following study, similarly to approach developed in [23-25]. However, right now we can suggest that registered Urd $\bullet T i l \cdot 2 \mathrm{H}^{2+}$ complexes can be stabilized by electrostatic interactions of partially negatively charged two carbonyl groups of uridine and positively charged quaternary ammonium groups of tilorone. The partially negatively charged carbonyl groups of thymidine may be less sterically accessible, because of methylation of $\mathrm{C}_{5}$ of pyrimidine cycle in thymidine, that can cause less stability of noncovalent complexes of tilorone with thymidine (the complexes are not recorded in the mass spectrum). As for adenosine, in its structure there are no carbonyl groups with significant partial negative charge, and therefore electrostatic interactions of adenosine with positively charged protonated groups of tilorone will be weaker in comparison with the ones for uridine.

Taking into account that uridine is affiliated just with RNA (but not DNA) the obtained data testifies to the possible specificity of interactions of tilorone with the RNA (not DNA) components, which can be important for revealing the mechanisms of the tilorone biological activity.

\section{CONCLUSIONS}

The performed DLS investigations reveal the formation of large-scale molecular aggregates of tilorone with ssRNA in the buffer solution contained RNA-free phosphate buffered saline solution and $10 \%$ of fetal bovine serum, which is similar to the physiological solution in physical and chemical characteristics. The addition of tilorone into the ssRNA solution in the buffer in the molar ratio of 1:10 results in the formation of complexes of ssRNA particles with tilorone with the mean diameter of 10 times larger than the diameter of the particles in the ssRNA solution itself. We suggest that similar complexation of tilorone with ssRNA could take place in real biological systems and could provoke the tilorone antiviral effect as well as induce activation of interferon-mediated or interferon independent pathways of formation of antiviral resistance of the host cells.

The ESI mass spectrometric study of the model systems of (tilorone + nucleosides) (Ado, Urd, or Thd) demonstrates the formation of stable noncovalent complexes Urd $\bullet$ Til $\bullet 2 \mathrm{H}^{2+}$, while the complexes of tilorone with Ado and Thd are not detected in the experiments. It testifies to the possibility of formation of stable noncovalent complexes of tilorone with the RNA and their components in biological systems and pointed at Urd as one of the potential 
centers of specific binding of tilorone to the RNA molecules. Such intermolecular interactions of tilorone with viral RNA and/or with RNA in the host cells could be considered as the molecular mechanism of antiviral activity of tilorone as well as the molecular basis of the possible drug toxicity for the host cells.

\section{ACKNOWLEDGEMENTS}

Authors acknowledge the program of cooperation between the National Academy of Sciences of Ukraine and Hungarian Academy of Sciences for the financial support of the visit to the Institute of Organic Chemistry of Research Center of Natural Sciences of the Hungarian Academy of Sciences in Budapest (Hungary), where the mass spectrometry experiments were done. Authors also thank Dr. Ivanov A. from B. Verkin Institute for Low Temperature Physics and Engineering of the National Academy of Sciences of Ukraine for the nucleosides samples providing.

\section{CONFLICT OF INTERESTS}

The authors declare that there is no conflict of interest.

\section{Authors' ORCID ID}

V.A. Pashynska (iD https://orcid.org/0000-0001-9786-6828

N.M. Zholobak (D) https://orcid.org/0000-0003-2792-9787

M.V. Kosevich (i) http://orcid.org/0000-0003-0257-4588

A. Gomory (iD https://orcid.org/0000-0001-5216-0135

P.K. Holubiev (D) https://orcid.org/0000-0003-3437-4986

A.I. Marynin (iD https://orcid.org/0000-0001-6692-7472

\section{REFERENCES}

1. Krueger R. E., Mayer G. D. Tilorone hydrochloride: an orally active antiviral agent // Science. 1970. Vol. 16(3951). P. 1213-1214. doi: 10.1126/science.169.3951.1213.

2. Mayer G. D., Krueger R. E. Tilorone hydrochloride: mode of action // Science. 1970. Vol. 169(3951). P. 1214-1215. doi: 10.1126/science.169.3951.1214

3. Stringfellow D. A., Glasgow L. A. Tilorone hydrochloride: an oral interferon-inducing agent // Antimicrobial Agents and Chemotherapy. 1972. Vol. 2(2). P. 73-78. doi: 10.1128/AAC.2.2.73

4. Ekins S., Lingerfelt M. A., Comer E. A., Freiberg A. N., Mirsalis J. C., O’Loughlin K., Harutyunyan A., McFarlane C., Green C. E., Madrid P. B. Efficacy of Tilorone Dihydrochloride against Ebola Virus Infection // Antimicrobial Agents and Chemotherapy. 2018. Vol.62(2). pii: e01711- e01717. doi:10.1128/AAC.01711-17

5. Калюжин О. В. Тилорон как средство выбора для профилактики и лечения острых респираторных вирусных инфекций // Лечащий врач. 2013. №1. С. 1-6. https://www.lvrach.ru/2013/10/15435831/.

6. Peniche A. G., Osorio Y., Renslo A. R., Frantz D. E., Melby P. C., Travi, B.L. Development of an ex vivo lymph node explant model for identification of novel molecules active against Leishmania major // Antimicrobial Agents and Chemotherapy. 2014. Vol. 58(1). P. 78-87. doi: 10.1128/AAC.00887-13.

7. Wissing M. D., Dadon T., Kim E., Piontek K. B., Shim J. S., Kaelber N. S., Liu J. O., Kachhap S. K., Nelkin B. D. Small-molecule screening of PC3 prostate cancer cells identifies tilorone dihydrochloride to selectively inhibit cell growth based on cyclin-dependent kinase 5 expression // Oncology Reports. 2014. Vol. 32. P. 419-424. doi: 10.3892/or.2014.3174.

8. Zhou D., Tuo W., Hu H., Xu J., Chen H., Rao Z., Xiao Y., Hua X., Liu P. Synthesis and activity evaluation of tilorone analogs as potential anticancer agents // European Journal of Medicinal Chemistry. 2013. Vol. 64. Р. 432-441. doi: 10.1016/j.ejmech.2013.03.050.

9. Григорян С. С., Исаева Е. И., Бакалов В. В., Осипова Е. А., Бевз А. Ю., Простяков И. В., Надоров С. А. Амиксин - индукция интерферонов альфа, бета, гамма и лямбда в сыворотке крови и легочной ткани // РМЖ «Медицинское обозрение».2015. №2. С.93-99.

10. Zhuk M., Sumriy S. K. Zhuk O. V. Elimination kinetics of synthetic interferon inducer tilorone in experimental animals // Journal of Pre-Clinical and Clinical Research. 2017. Vol. 11(2). P. 127-131. doi: 10.26444/jpccr/81165.

11. Ratan R. R., Siddiq A, Aminova L., Langley B., McConoughey S., Karpisheva K.,... Gazaryan, I. Small molecule activation of adaptive gene expression: tilorone or its analogs are novel potent activators of 
Study of intermolecular interactions of antiviral agent tilorone with RNA and nucleosides.

hypoxia inducible factor-1 that provide prophylaxis against stroke and spinal cord injury // Annals of the New York Academy of Sciences. 2008. Vol. 1147 (1). P. 383-394. doi: 10.1196/annals.1427.033.

12. Feng J., Weitner M., Shi W., Zhang S., Sullivan D., Zhang Y. Identification of Additional Anti-Persister Activity against Borrelia burgdorferi from an FDA Drug Library // Antibiotics. 2015. Vol. 4(3). P. 397-410. doi: 10.3390/antibiotics4030397.

13. Giron D. J., Schmidt J. P., Pindak F. F. Tilorone hydrochloride: lack of correlation between interferon induction and viral protection // Antimicrobial Agents And Chemotherapy. 1972. Vol. 1(1). P. 78-79. doi: 10.1128/AAC.1.1.78.

14. Chatterjee S. S., Chakraborty T. Isolation of bacterial RNA from cultures // In D. Lin (Ed.) Handbook of nucleic acid purification. Boca Raton: CRC Press Taylor@Francis Group, 2009. P. 107-128.

15. Stetefeld J., McKenna S., Patel T. R. Dynamic light scattering: a practical guide and applications in biomedical sciences // Biophysical Reviews. 2016. Vol. 8 (4). P. 409-427. doi: 10.1007/s12551-016-0218-6.

16. Karpov A.V., Zholobak N. M., Spivak N. Y., Rybalko S. L., Antonenko S. V., Krivokhatskaya L. D. Virusinhibitory effect of a yeast RNA - tilorone molecular complex in cell cultures // Acta virologica. 2001. Vol. 45(3). Р. 181-184.

17. Карпов А. В., Жолобак Н. М. Изучение интерфероногенных свойств комплексов РНК-тилорон в культуре клеток // Антибиотики и химиотерапия. 1995. Т. 40, №5. С. 20-23.

18. Карпов А. В., Жолобак Н. М. Продукция интерферонов I типа в организме под действием молекулярных комплексов дрожжевая РНК-тилорон // Вопросы вирусологии. 1996. Т.41, № 1. С. 13-16.

19. Pirher N., Ivicak K., Pohar J., Bencina M., Jerala R. A second binding site for double-stranded RNA in TLR3 and consequences for interferon activation // Nature Structural \& Molecular Biology. 2008. Vol. 15(7). P. 761-763. doi: 10.1038/nsmb.1453

20. DeWitte-Orr S. J., Mehta D. R., Collins S. E., Suthar M. S., Gale M., Mossman K. L. Long DoubleStranded RNA Induces an Antiviral Response Independent of IFN Regulatory Factor 3, IFN- $\beta$ Promoter Stimulator 1, and IFN // The Journal of Immunology. 2009. Vol. 183(10). P. 6545-6553. doi: 10.4049/jimmunol.0900867.

21. Pashynska V. A., Kosevich M. V., Van den Heuvel H., Claeys M. Characterization of noncovalent complexes of antimalarial agents of the artemisinin type and Fe(III)-heme by electrospray ionization mass spectrometry and collisional activation tandem mass spectrometry // Journal of the American Society for Mass Spectrometry. 2004. Vol. 15. P. 1181-1190.

22. Pashynska V. A., Kosevich M. V., Gomory A., Vekey K. Investigations of the formation of noncovalent complexes between antimicrobial agent ethonium with membrane phospholipids by electrospray ionization mass spectrometry // Mass-Spectrometria. 2012. Vol. 9(2). P. 121-128.

23. Pashynska V., Kosevich M., Stepanian S., Adamowicz L. Noncovalent complexes of tetramethylammonium with chlorine anion and 2,5-dihydroxybenzoic acid as models of the interaction of quaternary ammonium biologically active compounds with their molecular targets. A theoretical study //Journal of Molecular Structure: THEOCHEM. 2007. Vol. 815. P. 55-62. doi:10.1016/j.theochem.2007.03.019.

24. Pashynska V., Stepanian S., Gomory A., Vekey K., Adamowicz L. Competing intermolecular interactions of artemisinin-type agents and aspirin with membrane phospholipids: Combined model mass spectrometry and quantum-chemical study // Chemical Physics. 2015. Vol. 455. P. 81-87. doi:10.1016/j.chemphys.2015.04.014.

25. Pashynska V., Stepanian S., Gomory A., Vekey K., Adamowicz L. New cardioprotective agent flokalin and its supramolecular complexes with target amino acids: An integrated mass-spectrometry and quantumchemical study // Journal of Molecular Structure. 2017. Vol. 1146. P. 441-449. doi:10.1016/j.molstruc.2017.06.007.

\section{REFERENCES}

1. Krueger, R.E., Mayer, G.D. (1970) Tilorone hydrochloride: an orally active antiviral agent. Science, 16(3951), 1213-1214. doi: 10.1126/science.169.3951.1213.

2. Mayer, G.D., Krueger, R.E. (1970). Tilorone hydrochloride: mode of action. Science, 169(3951), 12141215. doi: 10.1126/science.169.3951.1214.

3. Stringfellow, D.A., Glasgow, L.A. (1972). Tilorone hydrochloride: an oral interferon-inducing agent. Antimicrobial Agents and Chemotherapy, 2(2), 73-78. doi: 10.1128/AAC.2.2.73.

4. Ekins, S., Lingerfelt, M.A., Comer, E.A., Freiberg, A.N., Mirsalis, J.C., O’Loughlin, K., Harutyunyan, A., McFarlane, C., Green, C.E., Madrid, P.B. (2018). Efficacy of Tilorone Dihydrochloride against Ebola Virus Infection. Antimicrobial Agents and Chemotherapy, 62(2), e01711-e01717. doi:10.1128/AAC.01711-17.

5. Kalugin, O.V. (2013). Tilorone as a chosen preparation for prevention and treatment of acute respiratory viral infections. Lechebnoe delo, (10), 1-6. (in Russian) https://www.lvrach.ru/2013/10/15435831/.

6. Peniche, A.G., Osorio, Y., Renslo, A.R., Frantz, D.E., Melby, P.C., Travi, B.L. (2014). Development of an ex vivo lymph node explant model for identification of novel molecules active against Leishmania major. Antimicrobial Agents and Chemotherapy, 58(1), 78-87. doi: 10.1128/AAC.00887-13. 
7. Wissing, M.D., Dadon, T., Kim, E., Piontek, K.B., Shim, J.S., Kaelber, N.S., Liu, J.O., Kachhap, S.K., Nelkin, B.D. (2014). Small-molecule screening of PC3 prostate cancer cells identifies tilorone dihydrochloride to selectively inhibit cell growth based on cyclin-dependent kinase 5 expression. Oncology Reports, 32, 419-424. doi: 10.3892/or.2014.3174.

8. Zhou, D., Tuo, W., Hu, H., Xu, J., Chen, H., Rao, Z., Xiao, Y., Hua, X., Liu, P. (2013). Synthesis and activity evaluation of tilorone analogs as potential anticancer agents. European Journal of Medicinal Chemistry, 64, 432-441. doi:10.1016/j.ejmech.2013.03.050.

9. Grigoryan, S.S., Isaeva, E.I., Bakalov, V.V., Osipova, E.A., Prostyakov, I.V., Nadorov, S.A. (2015). Amixin: induction of interferons- $\alpha,-\beta,-\gamma$ and $-\lambda$ in serum and lung tissue. Russkii Meditsinskii Zhurnal, (2), 93-99. (in Russian)

10. Zhuk, M., Sumriy, S.K., Zhuk, O.V. (2017). Elimination kinetics of synthetic interferon inducer tilorone in experimental animals. Journal of Pre-Clinical and Clinical Research, 11(2), 127-131. doi: 10.26444/jpccr/81165.

11. Ratan, R.R., Siddiq, A, Aminova, L., Langley, B., McConoughey, S., Karpisheva, K., Gazaryan, I. (2008). Small molecule activation of adaptive gene expression: tilorone or its analogs are novel potent activators of hypoxia inducible factor-1 that provide prophylaxis against stroke and spinal cord injury. Annals of the New York Academy of Sciences, 1147(1), 383-394. doi: 10.1196/annals.1427.033.

12. Feng, J., Weitner, M., Shi, W., Zhang, S., Sullivan, D., Zhang, Y. (2015). Identification of Additional Anti-Persister Activity against Borrelia burgdorferi from an FDA Drug Library. Antibiotics, 4 (3), 397410. doi: 10.3390/antibiotics4030397.

13. Giron, D.J., Schmidt, J.P., Pindak, F.F. (1972). Tilorone hydrochloride: lack of correlation between interferon induction and viral protection. Antimicrobial Agents and Chemotherapy, 1(1), 78-79. doi: 10.1128/AAC.1.1.78.

14. Chatterjee, S.S., \& Chakraborty, T. (2009). Isolation of bacterial RNA from cultures. In D. Lin (Ed.) Handbook of nucleic acid purification (pp. 107-128). Boca Raton: CRC Press Taylor@Francis Group.

15. Stetefeld, J., McKenna, S., Patel, T.R. (2016). Dynamic light scattering: a practical guide and applications in biomedical sciences. Biophysical Reviews, 8(4), 409-427. doi: 10.1007/s12551-016-0218-6.

16. Karpov, A.V., Zholobak, N.M., Spivak, N.Y., Rybalko, S.L., Antonenko, S.V., Krivokhatskaya, L.D. (2001). Virus-inhibitory effect of a yeast RNA - tilorone molecular complex in cell cultures. Acta virologica, 45(3), 181-184.

17. Karpov, A.V., \& Zholobak, N.M. (1995). The interferonogenic properties of yeast RNA-tilorone complexes in a cell culture. Antibiotiki i khimioterapiia, 40(5), 20-23. (in Russian)

18. Karpov, A.V., Zholobak, N.M. (1996). Production of type I interferons in the body exposed to yeast RNAtiloron molecular complexes. Voprosy virusologii, 41(1), 13-16. (in Russian)

19. Pirher, N., Ivicak, K., Pohar, J., Bencina, M., Jerala, R. (2008). A second binding site for double-stranded RNA in TLR3 and consequences for interferon activation. Nature Structural \& Molecular Biology, 15(7), 761-763. doi: 10.1038/nsmb.1453.

20. DeWitte-Orr, S.J., Mehta, D.R., Collins, S.E., Suthar, M.S., Gale, M., Mossman, K.L. (2009). Long Double-Stranded RNA Induces an Antiviral Response Independent of IFN Regulatory Factor 3, IFN- $\beta$ Promoter Stimulator 1, and IFN. The Journal of Immunology, 183(10), 6545-6553. doi: 10.4049/jimmunol.0900867.

21. Pashynska, V.A., Kosevich, M.V., Van den Heuvel, H., Claeys, M. (2004). Characterization of noncovalent complexes of antimalarial agents of the artemisinin type and Fe(III)-heme by electrospray ionization mass spectrometry and collisional activation tandem mass spectrometry. Journal of the American Society for Mass Spectrometry, 15, 1181-1190.

22. Pashynska, V.A., Kosevich, M.V., Gomory, A., Vekey, K. (2012). Investigations of the formation of noncovalent complexes between antimicrobial agent ethonium with membrane phospholipids by electrospray ionization mass spectrometry. Mass-Spectrometria, 9(2), 121-128.

23. Pashynska, V., Kosevich, M., Stepanian S., Adamowicz L. (2007). Noncovalent complexes of tetramethylammonium with chlorine anion and 2,5-dihydroxybenzoic acid as models of the interaction of quaternary ammonium biologically active compounds with their molecular targets. A theoretical study. Journal of Molecular Structure: THEOCHEM, 815, 55-62. doi:10.1016/j.theochem.2007.03.019.

24. Pashynska, V., Stepanian, S., Gomory, A., Vekey, K., Adamowicz L. (2015). Competing intermolecular interactions of artemisinin-type agents and aspirin with membrane phospholipids: Combined model mass spectrometry and quantum-chemical study. Chemical Physics, 455, 81-87. doi:10.1016/j.chemphys.2015.04.014.

25. Pashynska, V., Stepanian, S., Gomory, A., Vekey, K., Adamowicz L. (2017). New cardioprotective agent flokalin and its supramolecular complexes with target amino acids: An integrated mass-spectrometry and quantum-chemical study. Journal of Molecular Structure, 1146, 441-449. doi:10.1016/j.molstruc.2017.06.007. 